UDC: 378.091.013: 785.

\section{Цитування:}

Ovcharenko N. Vocal methodology: on the problem of system research [Вокальная методология: к проблеме системного исследования]. Вісник Національної академії керівних кадрів культури i мистеитв : наук. журнал. 2020. № 3. С. 166170.

Ovcharenko N. (2020). Vocal methodology: on the problem of system research. National Academy of Culture and Arts Management Herald: Science journal, 3, 166-170 [in Ukrainian].

\author{
Ovcharenko Nataliya, \\ Doctor of Sciences (Pedagogics) \\ Professor of Methods, Musical Instruction, \\ Singing and Choral Conducting Department \\ Kryvyi Rih State Pedagogical University \\ ORCID: https://orcid.org/0000-0003-4874-1716 \\ shvager77@gmail.com
}

\title{
VOCAL METHODOLOGY: ON THE PROBLEM OF SYSTEM RESEARCH
}

The purpose of the article is to systematize the scientific methods of learning the art of singing on four levels of vocal methodology. The methodology of the study is revealed at the philosophical, general scientific, specific scientific and technological levels, with its foundation comprising: a systemic approach to systematize and summarize the methods of learning the art of singing; analytical - to study the scientific experience of humanitarian knowledge in solving the stated problem; cultural studies - to study the essence of the art of singing as a phenomenon of musical culture; axiological - to identify the value of vocal methodology and the definition of values in the art of singing. The scientific novelty of the study lies in the systematization of scientific methods of learning the art of singing at four levels of vocal methodology. Conclusions. The vocal methodology, which we consider as a system of scientific metamethods of knowledge essence and specifics of the art of singing at four levels: philosophical, general scientific, specific scientific, and technological, is at the beginning of the path of reflection and research. The identification of methods of learning the art of singing at the four levels of vocal methodology enabled us to systematize general, general scientific, and special methods aimed at solving the current problems of vocal science.

Key words: vocal methodology, vocal science, vocal technologies, art of singing, systematization of cognitive methods.

Овчаренко Наталія Анатоліївна, доктор педагогічних наук, професор кафедри методики музичного виховання, співу та хорового диригування Криворізького державного педагогічного університету

Вокальна методологія: до проблеми системного дослідження

Мета дослідження - систематизація наукових методів пізнання мистецтва співу на чотирьох рівнях вокальної методології. Методологія дослідження розкрита на філософському, загальнонауковому, конкретнонауковому і технологічному рівнях, iï основу становлять: системний підхід для систематизації та узагальнення методів пізнання мистецтву співу; аналітичний - для вивчення наукового досвіду гуманітарного знання, спрямованого на рішення означеної проблеми; культурологічний - для дослідження сутності мистецтву співу як феномена музичної культури; аксіологічний - для виявлення значення вокальної методології та визначення цінностей мистецтва співу. Наукова новизна роботи полягає в систематизації наукових методів пізнання мистецтва співу на чотирьох рівнях вокальної методології. Висновки. Вокальна методологія, яку ми розглядаємо як систему наукових мета методів пізнання сутності й специфіки мистецтва співу на чотирьох рівнях: філософському, загальнонауковому, конкретнонауковому, технологічному, знаходиться на початку шляху усвідомлення та дослідження. Виявлення методів пізнання мистецтва співу на чотирьох рівнях дало можливість систематизувати всезагальні, загальнонаукові та спеціальні методи пізнання, спрямовані на вирішення актуальних проблем вокальної науки.

Ключові слова: вокальна методологія, вокальна наука, вокальні технології, мистецтво співу, систематизація методів пізнання.

Овчаренко Наталия Анатольевна, доктор педагогических наук профессор кафедры методики музыкального воспитания, пения и хорового дирижирования Криворожского государственного педагогического университета

Вокальная методология: к проблеме системного исследования

Цель исследования - систематизация научных методов познания искусства пения на четырех уровнях вокальной методологии. Методология исследования раскрыта на философском, общенаучном,

(C) Ovcharenko N., 2020 


\section{Вісник Національної академії керівних кадрів культури і мистецтв № 3’2020}

конкретнонаучном и технологическом уровнях, ее основой являются: системный подход для систематизации и обобщения методов познания искусства пения; аналитический - для изучения научного опыта гуманитарного знания в решении заявленной проблемы; культурологический - для исследования сущности искусства пения как феномена музыкальной культуры; аксиологический - для выявления значения вокальной методологии и определении ценностей искусства пения. Научная новизна работы заключается в систематизации научных методов познания искусства пения на четырех уровнях вокальной методологии. Выводы. вокальная методология, которую мы рассматриваем как систему научных метаметодов познания сущности и специфики искусства пения на четырёх уровнях: философском, общенаучном, конкретнонаучном и технологическом, находится в начале пути осмысления и исследования. Выявление методов познания искусства пения на четырех уровнях вокальной методологии дало возможность систематизировать всеобщие, общенаучные и специальные методы, направленные на решение актуальных проблем вокальной науки.

Ключевые слова: вокальная методология, вокальная наука, вокальные технологии, искусство пения, систематизация методов познания.

Scientific relevance of the research topic. Undoubtedly, one of the most important problems of modern musicology and the pedagogy of musical art is a systematic study of the development of vocal methodology, the mastering of which will enhance the level of professionalism of future singers, vocal teachers, and music teachers, in particular. Today there is an urgent need for an analytical understanding of vocal methodology as a systemic phenomenon in solving current problems in the art of singing.

Analysis of recent researches and publications. In fact, any systematic study of vocal methodology has not yet been reflected in the scientific publications of any researchers. However, certain issues of the vocal methodology are highlighted in the works of contemporary Ukrainian and foreign scientists such as $\mathrm{V}$. Antoniuk [1], N. Hrebeniuk [2], V. Morozov [4], A. Stakhevich [6], V. Yushmanov [7].

The purpose of the article is to systematize the scientific methods of learning the art of singing on four levels of vocal methodology. Consequently, the methodology of the study is disclosed at the philosophical, general scientific, concrete scientific, and technological levels and its foundation is a systematic approach to systematize and summarize the methods of learning the art of singing; analytical - to study the scientific experience of humanitarian knowledge in solving the stated problem; cultural studies - to study the essence of the art of singing as a phenomenon of musical culture; axiological - to identify the value of vocal methodology and address the issues of the value worldview formation of the individual to the art of singing.

The presentation of the main material. In the history and theory of vocal performance and vocal pedagogy until the twentieth century, there is no clear distinction between the concepts of "vocal methodology" and "vocal methods". However, in the writings of some scholars of the first half of the $20^{\text {th }}$ century, certain historical and analytical scientific methods are applied to the knowledge of vocal art, and it is a question of vocal methodology, but not methods. At the same time, we have not identified a scientific explanation for the concept of "vocal methodology" in the works of modern scholars. Thus, determining the difference in the essence of these concepts is one of the most important problems of vocal science.

It should be noted that in modern scientific thought there is a pluralism of opinions in the understanding of the methodology, which is considered, in particular, as teaching about the organization of human activity; the connection between theoretical concepts and valid conclusions about the real world; principles of scientific research; the study of the scientific method of knowledge or a set of methods. Directly or indirectly, the reference characters of the methodology for many authors become the "method of cognition", which is a system of principles and techniques that must be guided in cognition. These are universal, general scientific, and special methods, the application of which is a specific study of the problem of scientific knowledge of the art of singing contributes to the creation of integrative, possibly new knowledge, which makes it possible to speak about creating a system of metamethods. Therefore, we consider the vocal methodology as a system of scientific metamethods of knowledge of the essence and specifics of the art of singing on four levels: philosophical, general scientific, concrete scientific, and technological; vocal technique - as a set of methods for solving practical problems of vocal performance or pedagogy.

Currently, in the study of actual problems of the art of singing, it is important to apply universal methods of cognition, which are the methods of philosophy: dialectic and metaphysical, intuitive, phenomenological, hermeneutic, semiotic, etc., the choice of which contributes to the development of a general strategy and the presentation of the cognitive 
regulative system in the research program on the "higher levels of cognition "[3, 15]. Each method is based on certain principles, such as, for example, the dialectical method includes the principles of reflection, activity, comprehensiveness, unity of deduction and induction, the relationship of qualitative and quantitative characteristics, determinism, historicism, contradiction, dialectical negation, the ascent from the abstract to the concrete, the unity of historical and logical, unity of analysis and synthesis.

Naturally, the study of the art of singing problems at the philosophical level of the vocal methodology is carried out using various sets of universal methods of knowledge, depending on the research program. For example, exploring the axiological foundations of vocal performance and vocal pedagogy, it is appropriate, in our opinion, to apply the method of interaction between the historical and logical, the analytical method, the method of forming the world outlook potential. Analyzing the views of philosophers on vocal activity from Antiquity to modernity, it can be determined that the origins of the value approach to vocal art should be sought for still in Antiquity. In the future, it is advisable to continue the study of the axiological foundations of vocal performance and vocal pedagogy by analyzing the works of philosophers of the Middle Ages, Renaissance and Modern times, the period of German classical philosophy, the second half of the 19th and the end of the 20th century, in order to conclude about the evolution of philosophical thought regarding the value of the art of singing.

Moreover, an important aspect in the awareness of the methodological significance of philosophical knowledge for the study of the art of singing is a deep understanding of the relationship of the universal laws of philosophy and the laws of the philosophy of musical art with the laws of vocal performance and pedagogy, among which are: the determination of the individual's value attitude to the vocal activity of the artistic and aesthetic influence of vocal art and vocal pedagogy; integrity and interrelation of all psycho-physiological singing processes; the causation of the emergence of new trends in the vocal art.

It is apparent that at the general scientific level vocal methodology, culturology, history, philology, general psychology, pedagogy, acoustics, anatomy, and psychophysiology are widely used to learn questions of vocal performance and vocal pedagogy. Accordingly, for completeness of the research, the research program includes general scientific methods of cognition: theoretical (analysis and synthesis, abstraction, synthesis, analogy, modeling, formalization, humanitarian dialogue), empirical (observation, conversation, survey, experiment), general logical (historical, systemic) structural and functional approaches.

In particular, an analytical study of the formation of vocal art in the context of the historical approach is presented in the work of A. Stakhevich, which identified three periods of formation of the European vocal tradition: the early period up to 1723 (the appearance of the first vocal-methodical treatise by Pietro Tosi), the period of the classical bel canto XVII century to the first third of the XIX and the period from the beginning of the XIX century to the present time $[6,7]$. Studying the Ukrainian vocal school, V. Antoniuk outlines the three stages of its development [1]: pre-classical - from the old Russian singing art (to the XVI century), classical - the formation of a professional school of choral art and its formation in the conditions of the foundations laying of solo singing (XVII-XIX) Art.), post-classical - the experience of professional high school fundamentals of teaching solo singing and the modern heyday of national schools of solo singing.

It can also be illustrated through the study of the art of singing from the standpoint of the scientific experience of anatomy and physiology, which includes theoretical methods: analysis, synthesis; general logical methods: a historical, systematic approach. In particular, the primary anatomical and physiological studies of the vocal process are reflected in the works of vocal teachers of singers in the XVI century. The works of the authors of the XVII - XVIII centuries reflect the empirical approach to the study of vocal sound. The creation of a laryngoscope in the nineteenth century contributed to the knowledge of the art of singing. Therefore, in the works of scientists of this time knowledge about the structure and function of the human voice apparatus, close to the modern, is highlighted. A significant breakthrough in the understanding of anatomy and physiology of vocal vocalization is associated with the development of the theory of higher nervous activity of man, identifying patterns of the transition of unconditioned reflexes into conditioned reflexes, as well as with the technical development of science, the appearance of electronic equipment for determining the overtone timbre and measuring strength voices of prominent singers. Eventually, such achievements gave the opportunity to modern scientists of the century to create a system of scientific knowledge 


\section{Вісник Національної академії керівних кадрів культури і мистецтв № 3’2020}

about the features of the anatomy and physiology of the singing process.

For the development of modern vocal science, specific methods of knowledge of the humanities, as well as methods of general psychology and pedagogy are actively used: psychoanalytic for observation and self-analysis of the vocal process; experimental; pedagogical or psychological testing for the diagnosis of emotional reactions; suggestive for creating an emotional state. Such modern research includes the experimental work of E. Meissner using psychological improvisational testing to study ways to increase the learnability of musicians in expressive performance, which is dialogical training or training to achieve emotional effect [10, 22 - 23].

The specific scientific level of vocal methodology reveals scientific vocal theories and special methods of studying the art of singing. The creation of voice-forming theories by scientists reflects the path of development of vocal science from empirical knowledge to scientific. In the middle of the XVIII century, certain attempts were made to explain the voice formation technology from the position of myoelastic theory, as a process of convergence of the vocal cords under the influence of air suspender pressure. And at the end of the $19^{\text {th }}$ century, theories of voice formation, which were not widely used in vocal practice, arose: aerodynamic, in accordance with which an assumption was made about the essence of voice formation as a result of the vortex movements of air in the ventricles of the larynx; myotatic, justifying the divergence and convergence of the vocal folds in the horizontal plane as a reflexive motion. In the mid-twentieth century, neurochronaxic theory, which focuses on the leading role of the central nervous system in vocalization and is based on the scientific method of measuring the excitability of nerve endings and muscle tissues, became widely popular. The study of the dependence of phonation on the state of the mucosa of the vocal apparatus is presented in the mucoondral theory of voice formation, according to which the oscillatory movements of the vocal folds are considered as wavy glides of the mucous membrane covering them. Among the contemporary vocal studies, a special place is occupied by the resonance theory of singing (4), in which the methods of acoustics, psychophysiology, and computer technologies are used for the scientific study of the role of resonators. A critical analysis of the theory and practice of vocal activity shows that modern research in the field of vocalization is based on myoelastic, neurochronaxic, mucoondral, resonance theories, in the context of which the methods of cognition of the singing process are myoelastic, neurochronaxic, mucoondral and resonant.

An example of a special method of learning the art of singing may be the method of "diagnosing vocal talent", authored by V. Morozov [4, 131]. Based on modern computer research, a new complex method has been developed, including both acoustic criteria (features of the high singing formant, vibrato) and physiological, psychophysiological, purely psychological, on which the singer's ability to master the resonant technique of singing, his musical and artistic expression and the ability to transform in the process of creating images of a musical work are involved.

In its turn, the technological level of the vocal methodology is represented by vocal methodologies, technologies, and individual methods of teaching vocal-performing and vocalpedagogical activity. In general, vocal science reveals the variety of methods for the development of a singer's voice, among which the most important ones are concentric, linear, spiral, phonetic, phonopedic, ideomotor, emotional voice tuning, vocal diagnostics, etc.

As a rule, the use of various musical technologies as well as the creation of specific vocal ones is among the new phenomena in the field of vocal performance and vocal pedagogy. Traditionally, learning solo singing takes place on the basis of the teacher's vocal use of the personality-oriented singing technique, and vocal technologies are characterized by a certain universality. These include technologies for developing children's voices, technologies for teaching pop singing. Today, students are particularly interested in the art of singing healthsaving technologies that allow them to restore a tired singing voice and preserve it for many years (M. Brunkan, J. Manternach) [8; 9]; technology of vocal coaching training, in the process of which the necessary competencies of a teacher-coach (S. Rudnev) are formed [5, 131]. On the one hand, some can argue about the feasibility of vocal technologies, the potential of which still needs to be explored, but, on the other, they have already gained wide popularity in teaching the art of singing practice.

Findings. Thus, the vocal methodology, which we consider as a system of scientific metamethods of knowledge of the essence and specifics of the art of singing at four levels: philosophical, general scientific, concrete scientific, and technological, is at the beginning of 
the path of reflection and research. In addition, the identification of methods of learning the art of singing at the four levels of vocal methodology made it possible to systematize general, general scientific, and special methods aimed at solving current problems in the vocal science sphere.

\section{Лimepamypa}

1. Антонюк В. Г. Українська вокальна школа: етнокультурологічний аспект : монографія. Київ : Українська ідея, 2001. 144 с.

2. Гребенюк Н. Є. Вокально-виконавська творчість : дис. ... д-ра мистецтвознавства : спец. 17.00.03 / Національна музична академія імені П. І. Чайковського. Київ, 2000. 369 с.

3. Кравец А. С. Методология науки. Воронеж : Изд-во Воронеж. гос. ун-та, 1991. 141 с.

4. Морозов В.П. Резонансная теория голосообразования. Эволюционно-исторические основы и практическое значение. Вокальное образование начала XXI века. Москва : Новый ключ, 2008. С. 121-131.

5. Руднева С. В. Феномен вокального коучинга в современном музыкальном образовании. Тамбов : Грамота, 2019. Том 12. Выпуск 3. С. 131 - 135.

6. Стахевич А. Г. Bel canto в западноевропейской опере XIX века, творчество, исполнительство, педагогика. LAP LAMBERT Academic Publshing, 2012. 416 c.

7. Юшманов В.И. Вокальная техника и ее парадоксы : монография. 2-е изд. Санкт-Петербург : ДЕАН, 2002. 128 c.

8. Brunkan M. C. Preservice Music Teacher Voice Health, and Voice Function Before and During Student Teaching. Journal of Music Teacher Education. 2018. No 3. P. 80-94.

9. Manternach J. N. Voice Use and SelfReported Voice Health of Preservice. Music Educators Journal of Music Teacher Education. 2015. No 24. P. 53-66.

10. Meissner H., Timmers R. Teaching young musicians expressive performance: an experimental study. Music Education Research. 2019. No 21:1. P. 20-39.

\section{References}

1. Antoniuk V. H. (2001). Ukrainian vocal school: ethnoculturological aspect: monograph. Kyiv: Ukrainska idea [in Ukrainian].

2. Hrebeniuk N. Y. (2000). Vocal - performing art: dissertation of doctor knowledge in art: spets. 17.00.03. Kyiv [in Ukrainian]

3. Kravec A. S. (1991). Methodology of science. Voronezh: Izd-vo Voronezh. gos. un-ta, 1991 [in Russian].

4. Morozov V. P. (2008). Theory creating of voice resonance. Historic evolutionary Fundamentals and Practical significance. Vokalnoe obrazovanie nachala XXI veka: m-ly nauchno-prakt. konf. Moskva: Novyj klyuch, 121-131 [in Russian].

5. Rudneva S. V. (2019). Phenomena of vocal couching in modern musical education. Tambov: Gramota, 12, 3, 131 - 135 [in Russian].

6. Stahevich A. G.(2012). Bel canto in west European opera XIX century, art, performing, pedagogic. LAP LAMBERT Academic Publshing [in Russian].

7. Yushmanov V. I. (2002). Vocal technic and its paradoxes: monograph: monografiya . Sankt-Peterburg : DEAN [in Russian].

8. Brunkan M. C. (2018). Preservice Music Teacher Voice Health, and Voice Function Before and During Student Teaching. Journal of Music Teacher Education, 3, 80-94 [in English].

9. Manternach J. N. (2015). Voice Use and SelfReported Voice Health of Preservice. Music Educators Journal of Music Teacher Education, 24, 53-66 [in English].

10. Meissner H., Timmers R. (2019). Teaching young musicians expressive performance: an experimental study. Music Education Research, 21:1, 20-39 [in English].

Стаття надійшла до редакиії 21.05.2020 Прийнято до друку 22.06.2020 